\title{
Analysis of Government Role Based on International Trade New
}

\section{Theory}

\author{
DAl Ting ${ }^{1, a}$ \\ ${ }^{1}$ Jiangxi college of foreign studies,NanChang,330099, China \\ aDDaiTing919@yeah.net
}

Keywords: Strategic trade policy, government role, national competitive advantage

\begin{abstract}
.
About the orientation of the government's role in a country's foreign trade is always a controversial issue in the international trade theory. Mercantilism thought the government should take strict control on international trade and advocated government adopting a policy of the limit the eight. Comparative advantage theory and factor endowment theory argue that the government should not intervene international trade; they advocated promoting the welfare of the countries by free trade. The new international trade theory produced in the 1980s - the theory of strategic trade policy believes that economies scale and imperfect competition market sponge structure, some measures can help to improve the level of a country's economic welfare through the proper use of strategic trade, fiscal policy measures and tariffs, subsidies. This theory will be the role of government in biochemical advocates government intervention in international trade in a positive way.
\end{abstract}

\section{A new international trade theory}

Krugman's New International Trade Theory written by Paul Krugman, an economics professor at Harvard University in the United States, is the most important works of the study of contemporary international trade theory, policy and law. Two famous professor of economics at Princeton university, Nash dixit and John Claude think that the appearance of the book will help people to have a new prospect of contemporary international trade, help people deepen the study of the contemporary international trade change some key problems, and provides a number of clues to solve these problems and solutions. As a result, the two professors think in the field of new international trade theory, krugman has not only become the most innovative senior theorists and also become a senior statesman because of its policy based on the principle of the system.

The most important theoretical innovation of new trade theory lies in introducing the theory of industrial organization, making international trade theory get rid of the bondage of a perfect competition assumption conditions. Imperfect competition in the market is a common phenomenon, while perfect competition is a special case. And there are also the phenomenon of increasing returns in economies scale and industry area, which is not the constant reward of economies scale. Setting the economies scale as the international trade research assumptions, it can prompt pattern of international division of labor and international trade of new reasons. Krugman has a special chapter, connecting the analysis of technology and trade with the new 
trade theory, making the dynamic analysis become an important support of the new trade theory, which shows that how the increasing return bring in by technological innovation lead to imperfect competition conditions, and, in turn, gives an illustration of the technology innovation necessary power monopoly.

Krugman realized the breakthrough of the old monopoly (traditional international trade theory) through innovation, reference, and established a new monopoly (comprehensive, condensation, ascending and the establishment of a new international trade theory basic system).Many aspects of traditional international trade theory transform into a new international trade theory. New international trade theory explains a series of dynamic phenomenon in the contemporary international trade which the traditional international trade theory fails to explain, such as intra-industry trade, foreign trade and international influence in the dual economic structure in the developing countries, endogenous technological innovation and international trade and economic growth, market access and international trade, protecting import why equal to boost exports, the role of strategic trade policy, the influence of international capital movement to the international trade and interaction, and so on.

The new international trade theory in the 1980s - Strategic Trade Policy believes in economies scale and imperfect competition market structure the proper use of Strategic Trade Policy measures such as tariffs, subsidies will help to improve the level of a country's economic welfare. This theory will be biochemical the role of government, advocated government intervention in international trade in a positive way. With the theory of strategic trade policy almost at the same time the country Competitive advantage theory, Competitive Advantages of Nations but think the government should not intervene directly in the international trade. The theory is that the government to create and maintain a country's competitive advantage is only a supplementary role. Strategic trade policy theory and national competitive advantage theory, as a representative of the new trade theory mainly on relevant government role positioning, though there are some similar views, but the basic point of view is different.

\section{The role of government in the Strategic Trade Policy}

Strategic trade policy theory thinks that economies scale will lead to competitive advantage, and the best way to achieve economies scale is the government intervention. The government should support "strategic" sectors with certain economies scale. The so-called "strategic" sectors have two kinds of circumstances, one kind is the existence of "economic rent" department, which is to make a domestic sector gain more "economic rent" from foreign competitors through the support of the government policy, which means excess monopoly profits under the imperfect competition market structure, such departments can be considered as strategic sectors (Brander and Spencer, 1981, 1985). Another kind is a big department of "external economy", the department can exert its great externality through the policy support, such departments can also be considered as a strategic sector (Ethier, 1982). Strategic trade policy theory is believed that government intervention plays a positive role to form the static and dynamic economies of scale (Krugman, 1984).

\section{A. The government intervention forms Static Economies Scale}

In the premise of imperfect competition and increasing marginal cost, the government can 
improve the output of domestic enterprises in the international market share and profit share through the protection of domestic companies or government support, so as to achieve the aim of increasing their welfare level. In the Cournot model, two oligopoly manufacturers under the condition of technical constant, the output achieves Nash equilibrium, both sides are unwilling to change production without any external force. Government supporting policies of the country's manufacturers certainly breaks the original balance and makes domestic manufacturers to expand production and become profitable.

\section{B. Government intervention to form Dynamic Economy Scale}

Static economies scale refers to manufacturer's diminishing marginal production cost with the increase of production, and the dynamic economies scale refers to the manufacturer's marginal production cost curve down as a whole with the improvement of technical level. Technology is the endogenous variable of economic growth; technology is a dynamic economy of scale formation of endogenous factors, while the progress of the government's intervention skill to the technology is of great significance. Strategic trade policy theory believes that the government can achieve the dynamic economies scale of the enterprise through the two main ways so as to expand the enterprise production share and profit share in the international market. The government intervention is taken into international trade theory analysis, which is the reinterpretation of the action of the government and its role in biochemistry is a great progress of international trade theory. Strategic trade policy thinks that the government intervention can improve the conclusion of a country's welfare level hypothesis. Conclusions of traditional trade theory of government intervention, thereby causing loss to the national welfare, can't be very well explained, and what's the reasons that mercantilist countries intervene in the foreign trade of traditional can exist so long in practice.

\section{The national competitive advantage theory and role of the government}

The national competitive advantage theory proposed by Porter, Michael suggests that a country's competitive advantage comes from four basic elements and two secondary factors (opportunities and the function of the government). Factors of production, domestic demand, related and supporting industries, enterprise's strategic structure and competition and so on four key elements are the basic factors to create a country's national competitive advantage, and the government can have a great impact on the four basic elements through its behavior and policy, and indirectly affects the national competitive advantage. Its action mechanism is mainly manifested in the following four aspects:

(1) The government can affect the factors of production through subsidies and education investment and policy such as capital market. National competitive advantage theory emphasized the important role of the government in providing advanced factors of production and specialized production factors.

(2) The state's influence on the demand conditions: on the one hand, the government formulated the local product specifications, affecting the customer demand; on the other hand, the government itself affects demand of the domestic market through the government procurement.

(3) The government can regulate media form of advertising or sales activity way to influence 
the related and supporting industries etc.

(4) The government can use financial market regulation, tax, antitrust law, anti-unfair competition law and policy tool to influence enterprise's strategic structure and competition.

Potter thinks the competitive advantage of the role of government in maintaining industry is properties. Government policy can only be effective in those existing industries with the four basic factors. Therefore, the first priority of the government is to try its best to create a good environment to support the productivity improvements. This means that the government should not interfere as far as possible in some aspects, such as trade barrier, pricing and etc. But in other aspects should play an active role, such as to ensure the strong competition, to provide high-quality education and training, provide the perfect infrastructure, and reduce the transaction cost of enterprises, the provision of public goods.

The government can use many ways to improve the operating environment of the enterprise, but must not restrict competition, or artificially reduce the safety and environmental standards, because the "help" of the government in some aspects actually can only hinder the company creation, delay the improvement of productivity, and thus affect the competitiveness of ascension.

Potter thinks that "citizens working in a safe environment with healthy and good education is very important for the improvement of productivity." (Michael porter, 1990) The national competitive advantage theory emphasizes the importance of a country's institutional environment, such as university, high school education institutions, the standard setting bodies, consumers' association, association of professional or legal system and etc. The country's competitiveness promotion plays a positive and constructive role, because all of these factors improve the productivity more or less. Therefore, countries should play a positive role in this type of system innovation.

\section{Comparative of the government's role of the two kinds of trade theory}

On the positioning of government role, while there are some similarities between the strategic trade policy theory and national competitive advantage theory, generally the two have a big difference. In comparison, the strategic trade policy theory puts more emphasis on the role of the government, thinking the government on the creation of a country's competitiveness and to develop in a dominant position. The national competitive advantage theory puts more emphasis on the role of the enterprise and market, thinking that the government is supporting role. The different positioning of the government is mainly displaying in the following:

(1) The strategic trade policy theory thinks that the government should participate in international competition, intervention in international trade, implement active industrial policy, and enhance the competitiveness of a country through the implementation of the strategic trade policy. International competitive advantage theory thinks that the international competition is between the enterprises and enterprises, but not between the nations, so the government should formulate policies to promote the improvement of the environment, which can produce this kind of environment and competitive opportunities for continued inventions to form a kind of pressure.

(2) The strategic trade policy theory thinks that the government should implement direct tariff protection, subsidies and other policies, domestic market. And national competitive advantage theory argues that the government directly interventions should not be implemented, and 
should not take the lead short-term static advantage policy, because these policies weakened the foundation of invention and innovation. "If the government reduces the cost of communications and transportation, reduces tariff barriers, improves the international competition, which are helpful to the innovation of the local industry,

(3) The strategic trade policy theory believes that the competitiveness of a country can be created by the government's policy. National competitive advantage theory believes that the government is not a basic part of diamond model, but is only a subsidiary elements. Government policy indirectly affects the country's competitive advantage through the influence of the four basic elements.

(4) The strategic trade policy theory believes that the protected industry can develop the international competitiveness in a relatively short period of time through the temporary, proper protection policy. The national competitive advantage theory suggests that a country's competitive advantage needs over decades, rather than one or two years of business cycle can be produced. Therefore, the most beneficial policy should focus on long-term plans, rather than short-term economic benefits.

(5) The strategic trade policy theory stresses that enterprise internal economies scale advantage, so the support policy objects should be one of the few enterprises or only a few industries. Internal economies scale and national competitive advantage theory are just price advantage, but in the international competition and in innovation is important, economic scale is not important. Potter's emphasis on enterprise is an important source of enterprise competitive advantage area of industrial cluster effect. So he thinks the government should spare no efforts in the establishment of regional brand, specialized services in the area of the construction and the public goods.

\section{Summary}

As Luis concluded on the role of government in economic development that "the government's failure may be due to either doing too little or doing too much". Without a wise government's actively promotions, no country can make any economic progress. On the other hand, there are many examples of the government brought disaster to the economic life, so to write a few pages full alert government involvement in economic life is also very easy." We should not only realize the government role in a country's economic development and define the government role in the suitable range in the international trade.

\section{References}

[1] Brander, J.A. and B.J.Spencer. Tariffs and Extraction of Foreign Monopoly Rents under Potential Entry. Canadian Journal of Economics, 1981, 14(3): 371-389.

[2] Ethier.W.. National and International Returns to Scale in the Modern Theory of International Trade. American Economic Review,1982, 72: 950-959

[3]Sheng Bin, New politic economy of trade protection, World Economy, 2001.

[4] Krugman, Paul R. Import Protection as Export Promotion. Monopolistic Competition International Trade.Oxford: Oxford University Press, 1984.

[5]Zhang Zhaojie, Popular internationalism, China Renmin University Press, 2000. 